\title{
POSTCOLONIAL TRAUMA IN INDIAN LITERATURE IN ENGLISH IN THE 21ST CENTURY
} Mail Marques de Azevedo*

(iD) https://orcid.org/0000-0002-3400-5227

Como citar este artigo: AZEVEDO, M. M. de. Postcolonial trauma in Indian literature in English in the 21st century. Todas as Letras - Revista de Lingua e Literatura, São Paulo, v. 22, n. 2, p. 1-12, maio/ago. 2020. DOI 10.5935/1980-6914/eLETLT2011962

Submissão: novembro de 2018. Aceite: abril de 2020.

Abstract: In the view of the Indian poet, Linguistics expert and novelist Rukmini Bhaya Nair, postcoloniality is an inherited psychic condition that requires going back to buried memories of colonial trauma in order to be cured. Considering Nair's inside perspective on colonialism as illustrative of that of postcolonial writers, this paper analyzes her views on the role of literature in today's India. Starting from the analysis of three of her essays in Lying on the postcolonial couch: the idea of indifference (2002), as well as of her novel Mad girl's love song (2013), this article comments on residues of colonialism in the 21 st century Indian literature and culture.

Keywords: Imperialism. Postcolonialism. Indian literature. Trauma. Rukmini Bhaya Nair. 


\section{INTRODUCTION}

I $\mathrm{n}$ The drowned and the saved, his meditation on the meaning of the Nazi extermination mechanism, 40 years after his liberation from Auschwitz, Primo Levi (1988, p. 23) wrote: "Human memory is a marvelous but fallacious instrument. [...] The further events fade into the past, the more the construction of convenient truth grows and is perfected". At the time when the neologism "post-truth" had been entered in dictionaries (2016), Levi's warning words would express to perfection the unavoidable consequences of historical oblivion. Oblivion is likewise the fate of postcoloniality in the view of Rukmini Bhaya Nair, the renowned poet, linguist and novelist writing in English in the 21st post-independence India: "Postcoloniality awaits consignment to oblivion. In this it is like all historical phenomena, fated to be committed to memory, then to institutions and thence to amnesia" (NAIR, 2002, p. xi). Furthermore, she says, postcoloniality is an inherited psychic condition requiring a cure that involves a return to buried memories of colonial trauma.

Colonial/postcolonial trauma underlies both Nair's essays on the consequences of colonialism collected in Lying on the postcolonial couch: the idea of indifference (2002) and her novel Mad girl's love song (2013). In order to fathom Nair's inside perspective on colonialism as illustrative of that of the postcolonial writer, this paper analyzes her views on the role of literature in today's India in three of her essays: "Colonization: Omeros Sails between the Indian Ocean and the Caribbean", "The pedigree of the white stallion", and "A fatwa against indifference? Of Shamianas, death and platonic censors".

Nair's novel, which is an intricate weaving of post-colonial fable and intertextuality, features a young character-narrator, a schizophrenic Indian girl who believes she flies on angel wings across the territories of her rich imagination, where she interacts with Sylvia Plath, William Blake and D. H. Lawrence. Schyzoid outbreaks lead the young girl-woman to search for answers to what lies in wait in the future, and for explanations about past events, which cannot be found in real life, in those imaginary relationships. She feels rejected by her wealthy tyrannical father, who commits the seven-year old girl orphaned by her mother's suicide to a Catholic convent in India, from where she emerges years later dazed and rootless.

Considering the girl's madness, induced by familial trauma, as a reflection of the collective schizophrenia of the postcolonial condition, our analysis uses Nair's fiction as an illustration of her conception of the traumatic consequences of colonialism.

\section{RESIDUES OF COLONIALISM IN POST-INDEPENDENCE INDIA}

In the two decades after the Second World War, around a hundred new states emerged having won independence from colonial rule. The largest number of these decolonizations occurred in what had been the British Empire, which, at its zenith in 1914, extended to some 12,700,000 square miles of the earth's surface, ranging from the Caribbean to the Indian sub-continent, Australia and large sections of Africa and Southeast Asia. 
Aijaz Ahmad situates India in the first phase - from 1945 to 1965 - of the periodization he offers for the emergence of large numbers of sovereign nation states through anticolonial movements in the twentieth century.

When states acquired independence under the leadership of their respective national bourgeoisies (some radical, others conservative) within the broad context of modernization and integration within the capitalist world system (apud SIVANANDAN, 2004, p. 54).

Optimism marked the years immediately following independence as the barriers of colonial racism were thrown aside and the possibilities for independent social, economic, and political development seemed within reach. In most cases such expectations were not fulfilled.

Partha Chaterjee, a leading member of the Subaltern Studies Group of historiography, shows in his work on nationalism in the Indian context that "anti-imperial nationalism can, in fact, become a panacea for not dealing with economic disparities, the need for social transformation, or the capture of the state by the national élite" (apud SIVANANDAN, 2004, p. 56). In spite of the political success achieved by nationalism for ending colonial rule, he argues, emotional trauma lives on in postcolonial India. Having many of these new leaders received an education under colonialism, often completed by studies in Europe, their mentality and culture remained deeply dependent, and "their rule continued the domination and exploitation of the people begun by imperialism" (apud SIVANANDAN, 2004, p. 57).

That is exactly Rukmini Bhaya Nair's (2002, p. ix) central argument in Lying on the postcolonial couch, in which she aims at bringing to life the "emotional residue [...] of colonial anxieties left unturned - desire, guilt, stoicism, apathy, frustration, boredom, embarrassment, fascination, excitement, loneliness, contempt, pain, amusement, cruelty, horror".

It is an impressive and colorful array of emotions overshadowed by the monochromatic gray of bureaucratic indifference, "with so much success that only the faintest traces remain of any affective content at all in the texts of the postcolony" (NAIR, 2002, p. xiii). It is these already almost unrecoverable "textual chromata" that the author wants to trace, "before the phenomenon of postcoloniality passes into obscurity" (NAIR, 2002, p. xiii). Ironically, neither the bureaucrats nor the people participated in the creation of the modern democratic institutions, to which they are now subject. If indifference, in Nair's view, is the central metaphor holding together the poetics of postcoloniality, then "the topos of indifference is the sacralized space of the bureaucracy" (NAIR, 2002, p. 226). On either side of that domain lie eutopos or the nowhere glory of an ideal utopia and dystopos or the ever present threat of Third World wretchedness (NAIR, 2002, p. 226).

In order to understand Rukmini's argument, it is necessary to make a brief historical retrospect of British colonialism in India, as from the early nineteenth century, when British expansionism, accomplished by treaty and annexation, but sustained by military force, extended in one third the country's territory. The voice of Parineeta, Nair's schizophrenic character-narrator in Mad girl's love song, wails in despair: "And slowly the fabled riches of the Indies fell like ripe plums into the hands of Company and Crown" (NAIR, 2013, p. 151).

By 1820, following the so-called Maranatha Wars, the East India Company controlled nearly half of the subcontinent. A series of bloody and costly wars 
waged by Britain assured the conquest of what is now Afghanistan and Pakistan allegedly to prevent Russian expansion southward toward India. Consequently, heavy taxation became necessary to finance British local armies. Expansions and accompanying technological innovations transformed India: the end of the Company's monopoly in 1813 and the opening of Indian markets to all comers proved devastating for Indian cotton weavers; however, modern communications and travel, in the form of the telegraph, the "penny post", and railroads began the process of unifying the country. It was the Company's contention that it respected indigenous religious institutions and had brought good government in the wake of conquest. In fact, the Company was the true power behind the façade of Indian Rajas and Nawabs. The fact that the East India Company itself was merely a pretense became clear with growing British governmental intervention and military conquest. The relationship between British colonizers - aggressively conscious of their scientific, technological, military, cultural, and religious superiority - and the humiliated indigenous population was not an easy one. Differences came to a head with the so-called Sepoy Mutiny of 1857-1859, known to Indians as the First War of Independence. Whether a Mutiny to be stifled with violence or a War for freedom, the armed conflict brought about political and psychological consequences: in 1858, India was proclaimed a crown colony, putting an end to the fiction of the Company's rule, harboring memories of massacres and treachery on either side left scars that never healed.

The period from 1858 to 1947 , known as the British Raj, marked the consolidation of the imperial power. In 1876, Queen Victoria received the title of "Empress of India" and, in official interpretation, the "golden age" of the Raj began. Underneath the golden veil, however, germs of revolt thrived:

The nexus oppression-rebellion is a stereotype. The history of rebellions, that is, of insurgencies or revolts from below by the many oppressed against the few powerful, is as old as the history of humanity and just as varied and tragic (LEVI, 1988, p. 158).

Scars of painful memories disfigure the psyche of Nair's protagonist, Parineeta, a postcolonial subject in post-independence India, who believes she is the inspiring force behind the great unreachable icons of Western literary canon, Plath, Blake, and Lawrence. Parineeta's direct indictment of colonialism comes to the fore in the second division of the novel, titled "William": "By the year 1800, when William was forty-three and at the height of his poetic powers, Clive's ragtag Company had grown fine and fatted" (NAIR, 2013, p. 151, emphasis added). She persuades a reluctant William Blake, her protégé-lover, to visit a menagerie to see the Tipu's Tiger widely advertised in London as "Cruel Flesh Eater of the East! Twenty hands from Tail to Ear! One of the Largest Beasts Ever to be Shewn in the Western Hemisphere!" (NAIR, 2013, p. 155). The language of the posters and bills "strewn about the city like bright angel confetti" lies in blatant contrast to that of Blake's in his immortal "Tyger". Parineeta's side comments illustrate the strength of the colonizer's manipulative discourse:

Well, first off, I must draw your attention to the fact that these events established the foundations that would ensure that William's "Tyger" would be immortal [...]. Those long hymnal measures - aabb, aabb, aabb: Tyger! Tyger! burning bright/In the forests of the night, / What immortal hand or eye/ Could 
frame thy fearful symmetry? - were to hypnotize brown-skinned schoolchildren across the length and breadth of India a whole century later, while a thousand real tigers annually vanished to the tune of scattered gunshots in night-forested Bengal! One day, irony of ironies, William's verses would be loved by a people he hardly knew [...] (NAIR, 2013, p. 151-152).

To this day, in fact, schoolchildren in India are educated in English language, literature and culture, as a result, primarily, of Thomas Babington Macaulay's 1835 educational project. The idea was that upper-caste Indian men would be British educated so as to be able to serve in the company's civil service ranks. "To Macaulay, Jones, and Heber India was conceptualized as the arena for utopian tryouts" (MACAULAY, 1997, p. 430). That policy, she argues, "initiated and sustained the myth of the monolithic Indian nation. I have named that violence, calling it indifference" (NAIR, 2002, p. 227). Nair's remark validates her position discussed above.

We refer again to the gap that grows wider with the passing of time between things as they were and things as they are represented, pointed out by Levi (1988, p. 157), "particularly by the current imagination fed by fiction, films and myths". If the representation of facts can be altered by fiction, the reverse must be true: to use literature to recover what remains unsaid underneath official reports in the "golden age". Rukmini regards Lying on the postcolonial couch a work about intersections between public, historicized institutional discourse, and private, hidden feelings that are the business of literature. "The grammar of the postcolonial", she says, "is most interestingly revealed through literary texts" (NAIR, 2002, p. xiii).

Postcolonial writers, in particular, from Wole Soyinka to Salman Rushdie, strenuously attempt to subvert the truths presented to us by the standard colonial histories. In this respect, genres such as the postcolonial novel actually offer competing accounts of historical events, redefining their contours in strange and illuminating ways (NAIR, 2016, p. 9-23).

\section{COMING UP FOR AIR}

Like a great part of Indian schoolchildren, Rukmini Bhaya Nair was "raised in India on a diet of English literature," in her own words "a quite maddening fate" (NAIR, 2013, p. 417). She became knowledgeable in the geography, history and literature of the UK and of the Commonwealth, but knew little about Africa, whereas Southeast Asia was absent from her school curricula. When she was invited to introduce Derek Walcott's poetry at a plenary session of the Association of Commonwealth Languages and Literatures in Mysore, in 1995, Rukmini realized that her knowledge of the poet himself, as well as of the Caribbean postcolonial, was restricted to information easily available in the media or in any basic guide to world literature. Reading Walcott's poems, namely his epic Omeros, however, raised a deep communion of feelings and the realization that "recovery from amnesia is always a matter of coming up for air and back into the world of language" (NAIR, 2002, p. 156, emphasis added) or, in other words, emerging from the depths of postcolonial trauma by means of one's literary talent to build a meaningful view of reality. Her essay, titled "Colonization: Omeros sails between 
the Indian Ocean and the Caribbean", therefore, explores some ways of discussing both Walcott's poetic persona and his version of the Caribbean postcolonial, that she came to understand throughout a series of significant encounters with a significant postcolonial "other" (NAIR, 2002, p. 157).

An extended book-length narrative, Omeros echoes the classic Homer's Iliad and some of his characters: the island fishermen Philoctet, Achille and Hector and, most relevantly, the black-skinned goddess-like Helen. In spite of common points, Walcott's Omeros stands as a revision of the canonic Mliad: his Helen is not a princess, but a low-class woman of exquisite beauty who commands every man's admiration and, in contrast to her Greek namesake, plays a major role in the action. In result of her extensive study of the poem, Rukmini suggests that Walcott is implicated in the production of a particular species of postcolonial theorizing that she calls "sensuous theory". References to particular points in the poem will illustrate the seven features of the theory proposed by Nair, synthesized in the sequence:

1. It must be recognized as an embedded critique, occurring within literary texts.

2. It is easily detachable from its literary context: it apparently engages with the rhetoric of colonization rather than with the history of colonization.

3. Its newly coined vocabulary circulates rapidly in the global academy.

4. It has a decidedly international flavor.

5. Its discourse is likely to be female-centered, but not necessarily feminist.

6. Most of the actors in the text are not just characters, but tropes.

7. Its language is formally exquisite, the language of international literary fashion, play, haute couture.

Rukmini's "sensuous theory" can be applied to the literary production of every postcolonial writer, her own novel included (NAIR, 2002, p. 155).

Indeed, we find in Mad girl's love song a fine demonstration of the main features of sensuous theory: the embedded or implied critique of colonialism is more often than not brought out into the open, in every division of the novel, as mentioned above. The idea of indifference, submission, and humiliation pervades Parineeta's analyses of her status as a dark-skinned mentally ill young girl physically restrained by white English doctors and nurses. Truly a colonial subject, however, Pari can get her way with her oppressors by the means of ruses and disguises: she manages to convince doctors that she is cured and is allowed to return home to her beloved Afi, the half-caste orphan raised by the convent sisters. Part of the theory's "mystique derives from textual cross-dressing or disguise", says Rukmini (NAIR, 2002, p. 166). Her novel, then, is the exemplary demonstration of disguise by means of intertextuality. She unabashedly uses Parineeta to deflate William Blake's passionate belief in America as the synonym of freedom, as well as Lawrence's poetry to criticize America's imperialism. Lawrence's "The evening land" is an ironic hymn of praise: 
Chart 1 - "The evening land"

Oh, America,

The sun sets in you

Are you the grave of our day? ...

I confess I am afraid of you ...

The catastrophe of your exaggerated love

You who never find yourself in love

But only love yourself further,

decomposing,

You who never recover from out of the

orgasm of loving ...
Even the winged skeleton of your bleached ideal

Is not so frightening as the clean smooth

Automation of your uprisen self,

Machine America

Dark, elvish

Modern, unissued, uncanny America

You nascent demon people

Lurking among the depths of your

industrial thicket

Allures me till I am beside myself

A nympholept. ...

Source: Nair (2013, p. 344).

In the novel's fictional world, it is Afi who comes to Pari's help and explains the meaning of the strange word: "Nympholepsy, Greek, denoting a frenzy of emotion for the unattainable" (NAIR, 2013, p. 345). The whole intricate fantasy, concocted by a sick feminine mind, expresses the postcolonial subject's unattainable desire of reversing the colonizer-colonized relationship. The features of international flavor, a female-centered but not necessarily feminist discourse, as well as a formally exquisite language are thus accounted for.

\section{READING BETWEeN THE LINES}

Like everything else, the issuing of official documents and reports, as well as the institution of literature itself - the publication and distribution of fiction or poetry - is under the direct control of the bureaucratic apparatus built by the ruling classes in the colony. How, then, can the unexpressed be recovered before postcoloniality is consigned to oblivion? Rukmini Bhaya Nair takes up that question as the theme for her essay "The pedigree of the white stallion: postcoloniality and literary history", in which she argues that it can be done by digging up the secret messages carried by superior contemporary texts like Rudyard Kipling's Kim and Rabindranath Tagore's Gora, as well as by texts meant for the masses or "crowds". Nair points out remarkable coincidences between the biographical facts of the two writers who lived in India - in Bombay and Calcutta, respectively - in the same period, although in opposite political and social positions: Kipling, an India-born apologist of imperialism; Tagore, an orthodox Bengali Brahmin who preached independence, but believed in cultural exchanges with the West. The two writers were born and died only a few years apart in the period roughly equivalent to that of the British Raj (1858-1947) - Tagore's life spanned from 1861 to 1941 ; Kipling's, from 1865 to 1936 - and the fact that they had such different familial and ideological backgrounds speaks in favor of the essay's objectives: to devise, between the lines of these two contemporary master texts, a revealing panorama of coloniality and to discuss the different approaches of literary history and historiographic subalternism to what literary texts have to say. 
By privileging the class-based notion of subject-position over the individualistic point-of-view perspective traditionally favored in literary criticism, subalternism insists on the futility of any discussion of subjectivity, even the most esoteric, without reference to collective consciousness or power relations (NAIR, 2002, p. 45-46).

Thus, the task of historiographical subalternism is the recovery of unwritten histories. In this perspective, literature itself could be viewed as a sort of subhistory.

As a starting point, Nair analyzes the opening scene of Kipling's novel, which depicts Kim, a street urchin "from the hot and crowded bazaars", standing proudly on top of a cannon and squabbling with a group of children over the rights of each of them to climb the Zam-zammah. The indefatigable Kim teases the other boys who represent the medley of races in India: to Abdulllah, he says "All the Mussalmans fell off the Zam-zammah years ago!". Kim has no qualms pointing out everyone's failings: "The Hindus fell off the Zam-zammah too. The Mussalmans pushed them off", he chants to provoke little Chota Lal, whose father, the omniscient narrator informs, "was worth perhaps half a million sterling, but India is the only democratic land in the world" (NAIR, 2002, p. 46, emphasis added).

In this respect, Nair contradicts Edward Said, who ascribes the narrator's surprising affirmative to Kipling's absolute belief in the benefits of imperialism. For Kipling, Said argues, the British Empire had acquired the status of a virtual fact of nature, there was no conflict, therefore, between his love for India as his homeland and his status as a colonizer. To Nair, however, the very opening scene of the novel evidences Kipling's perception that the British might not be the last ones in the rise and fall of political powers of peoples ousted from the Zam-zammah.

Besides that, Kim obviously functions in various scenes in the novel as a symbol of India's unidentifiable masses ("as unremarkable a figure as ever carried his own and a few other folks' fate slung around his neck"): he is shown crawling on the ground and looking up at Creighton Sahib, his future mentor in the activity of carrying messages. Kim thinks in Hindustani and his English is sui generis: "Irish" becomes "Eye-rishti". Therefore, Nair concludes, a reading of Kim may certainly provide material for the collective's contestatory framework of subalternism, expressed by Gopal (2004, p. 139): “how is Indian history to be written outside the historically dominant frameworks, first of colonialism and, later of élite nationalism?".

Although no kind of intertextual borrowings of Kipling's pioneer Kim were ever acknowledged by Tagore, there are easily perceptible similarities between the two novels, which are titled after their protagonists, Kim and Gora, who are both orphans of Irish parents. Kim grows up in the street as the freest of spirits, whereas Gora is educated by Hindu parents and becomes an advocate for strict Hindu doctrine, believing that traditionalism is necessary under colonial rule. More than characters, both are tropes of the conflictual state of the colonial subject: although he is proud of his Irish father and his Redbull green regiment, Kim stands as a fragment of the Indian crowd; and for Gora, who ignores his true origin, the adversary is, in Patrick Hogan's words (2000, p. 233), "the pervasive, racist, criticism of Indian culture by the colonialists and the mimetic 
stratum of upper-class Indian society". The "delicious irony", as Nair points out, is that Kim and Gora are Irish and not "true" Englishmen: colonized societies may be different in terms of color, cultural level and geographical habitat; yet, as objects of discrimination, they are all the same.

\section{VIOLENCE, TRAUMA, AND MEMORY}

In the concluding chapter of Lying on the postcolonial couch - titled "A fatwa against indifference?" -, Rukmini Bhaya Nair examines some ironic implications of postcolonial death, which she has attempted to anticipate in the book, and ensuing reactions of bureaucratic indifference. Such is the case both of Salman Rushdie's announced death sentence, after the publication of The satanic verses, and the "already forgotten death of over four hundred, mostly children, trapped alive in a burning tent (shamiana) as they attended a school function on December 25, 1995" (NAIR, 2002, p. 225). Nair associates that cruel episode to the deaths by fire of the thousands trapped in the World Trade Center, in 2011. Both bureaucratic indifference and anti-imperialist terrorism can be seen as direct or indirect consequences of the traumatic experience of colonialism.

Equally serious is "the bias in self-perception associated with colonialism that had the effect of undermining the intellectual self-confidence of Indians", as pointed out by influential public thinker Amartya Sen (2006, p. 77), winner of the 1998 Nobel Prize in Economics. The broad interest in India's rich intellectual past shown by early colonial British administrators soon waned with the settlement of the empire and was replaced by coercion and dominance. As mentioned above, the construction of English literary education as a cultural ideal in British India became essential to the process of sociopolitical control. Thomas Macaulay's well known Minute on Indian education speeches in Parliament advocated the teaching of English as the only way to educate a people "who cannot at present be educated by means of their mother-tongue." It was of British interest forming "a class of persons, Indian in blood and colour, but English in taste, in opinion, in morals, and in intellect", that would function as interpreters between the Government and the great mass of the population (MACAULAY, 1997, p. 428, 430).

Successful both in her academic career and as a poet, essayist and novelist, Nair is conscious of the power and, better still, of the commitment of literature to fend off the residues of postcolonial subservience. In her seminal conference titled "The counterfactual course of literature: India as an imaginative space in the writings of Jose Saramago", she expresses her views on the role of literature:

A central raison d'être of fiction, in short, is that it experiments with the conventions and constructs of 'truth-telling'. Postcolonial writers, in particular, from Wole Soyinka to Salman Rushdie, strenuously attempt to subvert the truths presented to us by the standard colonial histories. In this respect, genres such as the postcolonial novel actually offer competing accounts of historical events, redefining their contours in strange and illuminating ways (NAIR, 2016).

Nair's novel Mad girl's love song, briefly analyzed above, offers an exemplary case of the contradictions that haunt postcolonial writers, whether scattered by the diaspora, or living in their mother country. Salman Rushdie himself, whom Rukmini elects "an experienced guide through the dangerous labyrinth of postcoloniality" (NAIR, 2002, p. 226), falls prey to the foremost indictment in both 
colonial and postcolonial times, the curse of censorship. "Of shamianas, death and the platonic censors", the subtitle of chapter 9, furnishes an important lead to evils of colonialism that survive in the age of technology, dramatically foregrounded through the Rushdie affair concerning The satanic verses. "How is it possible for mere words to cause moral wounds so deep as to make several people feel the only way such pain can be alleviated is to make the writer disappear, preferably forever?" Rukmini asks relevantly (NAIR, 2002, p. 233). Salman Rushdie has the gift of recording modern India's coming of age with great acumen in his fiction. However, he seems to be equally apt at raising controversy and intolerance.

Rushdie represents "trouble" in the collective unconscious of this nation. That spasmodic mental knee jerk with which we respond each time Rushdie taps smartly on a knobby surface is evidence of this. Rushdie is, so to speak, in our bones or, at any rate, possesses an enviably accurate knowledge of the anatomy of the subcontinent (NAIR, 2002, p. 238).

\section{CONCLUDING REMARKS}

A postcolonial writer with acute powers of observation, Rukmini Bhaya Nair provides us with an encompassing view of literary production in post-independence India and its relevance in overcoming the emotional trauma that lives on in postcolonial societies.

In her postscript to Lying on the postcolonial couch, she admits having blamed the government throughout the book for natural or man-made disasters that befall the people because of bureaucratic adherence to obsolete rules and laws. These attitudes are obvious replays of colonial impositions.

She recognizes that the task of the governments is made easier by treating their governed peoples as a uniform mass of humanity, as illustrated by $\mathrm{Ma}-$ caulay's Minute, but in the case of India this is a contradiction.

In spite of a common constitution (1949) India remains divided by a series of centuries-old cultural differences: language (fifteen constitutionally recognized languages, plus many others), religion, geography, economic and educational levels, plus the strict caste system which still survives in the XXIst century. In terms of education there exists a wide gulf between the level of education of urban dwellers and of tradition-bound rural peoples (NAIR, 2002, p. 252).

Economist Amartya Sen (2006, p. 28) points out that education can make a big contribution to reducing even inequalities related to the divisions of class and caste.

Despite living in her own country, Rukmini Bhaya Nair feels the need of using literature to subvert the myths of racial superiority and hegemony of the Western culture. More deeply disturbing is the situation of writers victimized by the voluntary diaspora of human groups - forced to leave their motherland by natural or economic, social and historical factors - whose prominent theme is the damaging consequences of colonialism. Such has been the path followed by some well-known writers whose work I have researched as, for example, the Indian-Caribbean V. S. Naipaul; the Anglo-Indian Salman Rushdie; and the Afro-British-American Caryl Phillips, besides the Pakistani Mohsin Hamid and the Caribbean Jamaica Kincaid, who chose to leave their countries as youngsters. 
Whether living in their motherlands or scattered by diaspora, postcolonial writers undoubtedly enjoy a privileged position to denounce stereotypes and prejudices used to brand the "other" who does not meet the ideal patterns of race, color and ancestry, even in this day and age. Rather than individual writers, they are postcolonial subjects committed to their self-appointed task of experimenting with the "conventions and constructs of truth-telling."

\section{O TRAUMA PÓS-COLONIAL NA LITERATURA INDIANA EM INGLÊS NO SÉCULO XXI}

Resumo: Na visão da poeta, especialista em Linguística e romancista Rukmini Bhaya Nair, a pós-colonialidade é uma condição psíquica hereditária que requer volta a memórias enterradas do trauma colonial para ser curada. Considerando a perspectiva interna de Nair sobre colonialismo como ilustrativa da visão dos escritores coloniais, este artigo analisa sua posição sobre o papel da literatura na Índia de hoje. A partir da análise de três de seus ensaios publicados em Lying on the postcolonial couch: the idea of indifference (2002) e do romance Mad girl's love song (2013), este artigo comenta os resíduos do colonialismo na literatura indiana e na cultura do século XXI.

Palavras-chave: Imperialismo. Pós-colonialismo. Literatura indiana. Trauma. Rukmini Bhaya Nair.

\section{REFERENCES}

GOPAL, P. Reading subaltern history. In: LAZARUS, N. (ed.). The Cambridge companion to postcolonial literary studies. Cambridge: Cambridge University Press, 2004. p. 139-161.

HOGAN, P. C. Colonialism and cultural identity: crises of tradition in the Anglophone Literatures of India, Africa and the Caribbean. New York: State of New York University Press, 2000.

LEVI, P. The drowned and the saved. New York: Summit Books, 1988.

MACAULAY, T. Minute on Indian education. In: ASHCROFT, B.; GRIFFITHS, G.; TIFFIN, H. (ed.). The postcolonial studies reader. New York: Routledge, 1997. p. $428-430$.

NAIR, R. B. Lying on the postcolonial couch: the idea of indifference. Minneapolis: University of Minnesota Press, 2002.

NAIR, R. B. Mad girl's love song. Noida, Uttar Pradesh: Harper Collins, 2013.

NAIR, R. B. The counterfactual course of literature: India as an imaginative space in the writings of José Saramago. In: FERNANDES, G. M. et al. Anais do III Congresso Internacional do PPG-Letras e do XVI Seminário de Estudos Literários: caminhos, contatos e contrastes [recurso eletrônico]. São José do Rio Preto: Ibilce-Unesp, 2016. p. 9-23.

SEN, A. The argumentative Indian: writings on Indian culture, history and identity. London: Penguin, 2006. 
LITERATURA

SIVANANDAN, T. Anticolonialism, national liberation, postcolonial nation formation. In: LAZARUS, N. (ed.). The Cambridge companion to postcolonial literary studies. Cambridge: Cambridge University Press, 2004. p. 41-65. 